

\section{PENGANTAR \\ KETAHANAN SOSIAL, EKONOMI, \\ DAN EKOLOGI}

YOSUA DAMAS SADEWO

PEBRIA DHENI PURNASARI

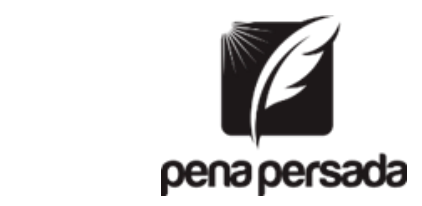

PENERBIT CV. PENA PERSADA 


\title{
PENGANTAR \\ KETAHANAN SOSIAL, EKONOMI, DAN EKOLOGI
}

\author{
Penulis: \\ Yosua Damas Sadewo \\ Pebria Dheni Purnasari \\ ISBN : 978-623-6504-88-8 \\ Design Cover : \\ Retnani Nur Briliant \\ Layout : \\ Hasnah Aulia \\ Penerbit CV. Pena Persada \\ Redaksi : \\ Jawa Tengah \\ Email : penerbit.penapersada@gmail.com \\ Anggota IKAPI \\ All right reserved \\ Cetakan pertama : 2020
}

Jl. Gerilya No. 292 Purwokerto Selatan, Kab. Banyumas

Website : penapersada.com Phone : (0281) 7771388

Hak cipta dilindungi oleh undang-undang. Dilarang memperbanyak karya tulis ini dalam bentuk apapun tanpa izin penerbit 


\section{KATA PENGANTAR}

Puji dan syukur kehadirat Tuhan Yang Maha Esa atas perkenaan-Nya buku Pengantar Ketahanan Sosial, Ekonomi, dan Ekologi dapat diselesaikan dengan baik.

Buku Pengantar Ketahanan Sosial, Ekonomi, dan Ekologi ini mengajarkan tentang hekekat, konsep, dasar-dasar dan pengertian Ketahanan Sosial, Ekonomi, dan Ekologi. Konsepsi Ketahanan Sosial, Ekonomi, dan Ekologi mengkaji dengan mendalam segisegi kekuatan Ketahanan Negara Indonesia yang potensial serta segi-segi yang masih rawan, sehingga dengan demikian buku ini dharapkan dapat memberi arah dan petunjuk yang jelas mengenai Ketahanan Sosial, Ekonomi, dan Ekologi di Indonesia. Buku Pengantar Ketahanan Sosial, Ekonomi, dan Ekologi ini menguraikan secara luas tentang "apakah Ketahanan Sosial, Ekonomi, dan Ekologi itu?" Kemudian menjelaskan hakekat, konsep, pengertian serta dasar-dasar dari Ketahanan Sosial, Ekonomi, dan Ekologi. Setelah membaca dan belajar mengenai Ketahanan Sosial, Ekonomi, dan Ekologi diharapkan ke depannya dapat berimpilkasi dan berkontribusi dalam peningkatan mutu kehidupan bermasyarakat, berbangsa, bernegara, dan kemajuan peradaban berdasarkan Pancasila; Berperan sebagai warga negara yang bangga dan cinta tanah air, memiliki nasionalisme serta rasa tanggungjawab pada negara dan bangsa; Memiliki semangat bela negara dan berorientasi pada peningkatan ketahanan nasional. Semoga Buku Ketahanan Sosial, Ekonomi, dan Ekologi ini dapat bermanfaat bagi penyusun dan lebih khusus bagi para pembaca.

Akhir kata, semoga buku Pengantar Ketahanan Sosial, Ekonomi, dan Ekologi ini dapat memberikan pemahaman pembelajaran mengenai Ketahanan Sosial, Ekonomi, dan Ekologi yang bermanfaat dan benar serta menyenangkan, sehingga mampu berperan dalam menghasilkan para generasi masa depan yang memiliki kepribadian berlandaskan pada Pancasila, Nasionalis dan Cinta tanah air.

Terimakasih dan mohon maaf apabila terdapat kekurangan maupun kesalahan dalam penulisan buku ini.

Deum Amare Et Amatum Facere Bengkayang, 13 Februari 2020

Penulis 


\section{DAFTAR ISI}

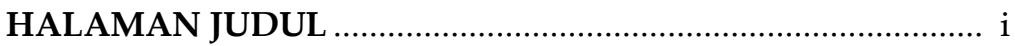

KATA PENGANTAR ................................................................ iii

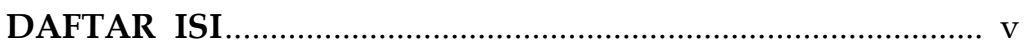

BAB I PENDAHULUAN

A. Sasaran Pembelajaran ...................................................... 1

B. Keterkaitan Ketahanan Sosial dan Ekonomi ................. 1

C. Manfaat atau Pentingnya Ketahanan Sosial dan Ekonomi ................................................................... 2

D. Penjelasan Belajar ........................................................ 3

BAB II Sejarah dan Konsep Ketahanan Nasional

A. Sejarah Ketahanan Nasional .......................................... 4

B. Falsafah Ketahanan Nasional.......................................... 8

C. Konsep Ketahanan Nasional ........................................... 12

D. Definisi Ketahanan Nasional.......................................... 16

E. Sifat Sifat Ketahanan Nasional..................................... 19

F. Unsur Unsur Ketahanan Nasional ................................ 20

G. Hakekat Ketahanan Nasional ...................................... 31

H. Kedudukan Dan Fungsi Ketahanan Nasional

Kedudukan Ketahanan Nasional..................................... 33

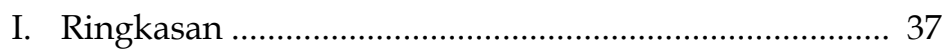

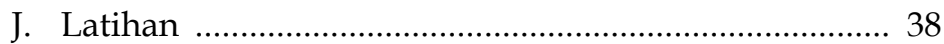

K. Umpan Balik ........................................................... 38

\section{BAB III Ketahanan Sosial}

A. Konsep Ketahanan Sosial ............................................ 39

B. Ketahanan Sosial dan Pembangunan

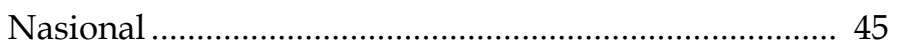

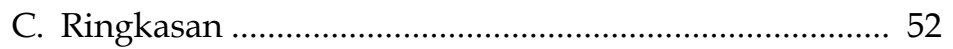

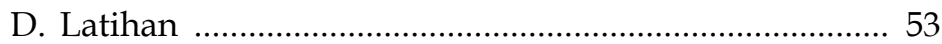

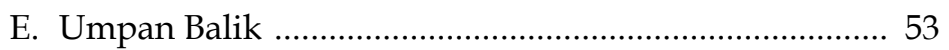




\section{BAB IV Ketahanan Ekonomi}

A. Konsep Ketahanan Ekonomi ........................................... 55

B. Ketahanan Ekonomi dalam Ketahanan

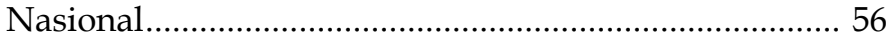

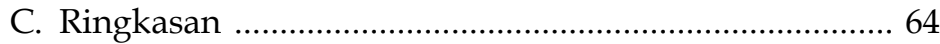

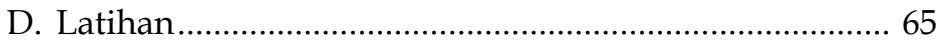

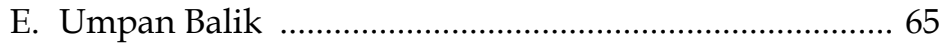

\section{BAB V Ketahanan Ekologi}

A. Konsep Ketahanan Ekologi............................................... 66

B. Ketahanan Ekologi dalam Mewujudkan

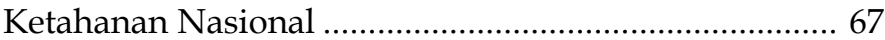

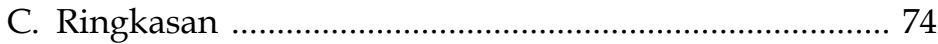

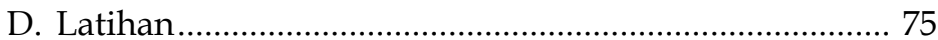

E. Umpan Balik ............................................................... 76

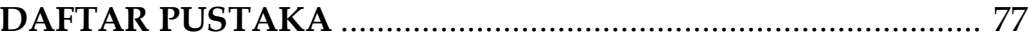





\section{BAB I \\ PENDAHULUAN}

\section{A. Sasaran Pembelajaran}

\section{Capaian Pembelajaran}

M1 : Mampu memahami sejarah, falsafah dan definisi ketahanan sosial, ekonomi, dan ekologi.

M2 : Mampu menguasai konsepsi serta unsur-unsur dari ketahanan sosial, ekonomi, dan ekologi.

M3 : Mampu menerapkan konsep ketahanan sosial, ekonomi, dan ekologi dalam mengkritisi permasalahan terkait kondisi ketahanan ketahanan sosial, ekonomi, dan ekologi di wilayah sekitar.

M4 : Mampu mengkaji permasalahan seputar ketahanan sosial, ekonomi, dan ekologi berdasarkan teori serta kajian yang sesuai.

M5 : Mampu menyampaikan hasil kajian permasalahan ketahanan sosial, ekonomi, dan ekologi baik secara lisan maupun tulisan

B. Keterkaitan (Ketahanan Sosial, Ekonomi, dan Ekologi) dengan pokok bahasan lainnya

Ketahanan sosial, ekonomi, dan ekologi merupakan pembelajaran yang memiliki capaian untuk dapat membantu pembaca memahami dasar-dasar ketahanan sosial, ekonomi, dan ekologi dengan baik dan benar sehingga karakter cinta tanah air, nasionalis, dan berjiwa Panacasila pada diri pembaca menjadi ada dan kuat. Tentunya salah satu wujud menjadi warga negara yang baik dalah dengan mengenali sejarah negaranya, mengerti aspek-aspek atau unsur-unsur utama dalam negaranya. Tidak hanya mengenali tetapi juga sangat diperlukan untuk memahami, mengerti, menghayati dan 
mempraktekkan. Generasi sekarang adalah generasi yang akan menerima tongkat estafet dari para pendahulu untuk meneruskan perjuangan negara Indonesia, oleh sebab itu sangat diperlukan untuk membekali generasi sekarang dengan wawasan ketahanan ketahanan sosial, ekonomi, dan ekologi yang baik dan benar dan yang sesuai dengan tujuan nasional negara Republik Indonesia.

\section{Manfaat atau Pentingnya Ketahanan Sosial, Ekonomi, dan Ekologi}

Ketahanan sosial, ekonomi, dan ekologi memiliki sesuatu yang khas yang tentunya berbeda dengan pembelajaran lainnya. Oleh karena kekhasaannya maka pembelajaran ketahanan sosial, ekonomi, dan ekologi tidak hanya mengajarkan bagaimana ketahanan nasional itu saja. Pembelajaran ketahanan sosial, ekonomi, dan ekologi merupakan sebuah pembelajaran yang fokus berisi tentang apa itu ketahanan nasional? Dan apa yang menjadi aspek penting dalam ketahanan nasional? Dan apa kegunaan ketahanan nasional itu?, mengapa ketahanan sosial, ekonomi dan ekologi menjadi bagian dari ketahanan nasional? dan yang kemudian dilanjutkan dengan konsep ketahanan sosial, ekonomi dan ekologi. Secara singkat manfaat dari mempelajari ketahanan sosial, ekonomi, dan ekologi ini adalah dapat mencerminkan diri sendiri sebagai sosok yang mencintai tanah airnya dengan indikator bahwa dia telah mengenal Ketahanan Nasionalnya dan dia dapat memahami aspek-aspek dalam ketahanan nasional dengan baik dan benar. Manfaat lainnya adalah mahasiswa dapat menjadi warga negara yang mencintai tanah airnya dengan melihat berbagai aspek penting dalam sebuah konsep ketahanan nasional. Oleh sebab itu sebuah pemahaman ketahanan nasional yang baik dan benar adalah hal yang penting untuk dimiliki terutama untuk generasi penerus. 


\section{Penjelasan Belajar}

Proses pembelajaran alami yang terjadi adalah pembaca akan mendapat materi-materi dari buku Pengantar Ketahanan Sosial, Ekonomi, dan Ekologi. Pembaca juga akan diberi rangkuman dari setiap materi dan juga disiapkan Latihan soal atau tugas untuk mengukur pemahaman yang sudah didapat. 


\section{BAB II \\ SEJARAH DAN KONSEP \\ KETAHANAN NASIONAL}

\section{A. Sejarah Ketahanan Nasional}

Di Indonesia istilah Ketahanan Nasional muncul pada tahun 1960-an, namun pada hakekatnya unsur ketahanan nasional sendiri telah ada sejak era 1900-an. Sejarah bangsa mencatat bahwa pada tanggal 20 Mei 1908 sebagai hari Kebangkitan Nasional. Kebangkitan Nasional ini memicu lahirnya kerangka pemikiran dalam mewujudkan Ketahanan Nasional di Indonesia. Selanjtunya istilah Ketahanan Nasional muncul dari kalangan militer angkatan darat di SSKAD (Sekolah Staf Komando Angkatan Darat) (Sunardi, 1997). Masa itu merupakan masa meluasnya pengaruh komunisme yang berasal dari Uni Soviet dan Cina. Fenomena tersebut mempengaruhi pemikiran para militer di SSKAD, mereka mengadakan pengamatan terhadap kejadian tersebut hasil pengamatannya menunjukkan bahwa tidak adanya perlawanan yang gigih dan ulet di Indonesia dalam menghadapi ekspansi komunis. Pengembangan atas pemikiran tersebut semakin kuat setelah berakhirnya gerakan G 30 S PKI.

Gejala tersebut mempengaruhi para pemikir di lingkungan SSKAD atau sekarang SESKOAD (Sunardi, 1997:12). Mereka mengadakan pengamatan dan kajian atas kejadian tersebut. Tahun 1960-an gerakan komunis semakin masuk ke wilayah Philipina, Malaysia, Singapura dan Thailand. Di tahun 1965 komunis Indonesia bahkan berhasil mengadakan pemberontakan (Gerakan 30 September 1965) yang akhirnya dapat diatasi. Menyadari akan hal tersebut, maka gagasan tentang masalah kekuatan dan unsur-unsur apa saja yang ada dalam diri bangsa Indonesia serta apa yang seharusnya dimiliki agar kelangsungan hidup bangsa Indonesia terjamin di masa-masa mendatang terus menguat. Pada tahun 1968 pemikiran tersebut dilanjutkan oleh Lemhanas 
(Lembaga Pertahanan Nasional). Kesiapan menghadapi tantangan dan ancaman itu harus diwujudkan dalam bentuk ketahanan bangsa yang dimanifestasikan dalam bentuk perisai (tameng) yang terdiri dari unsur-unsur ideologi, ekonomi, sosial budaya. Tameng yang dimaksud adalah wujud dari konsep kekuatan dari SSKAD.

Pemikiran di lingkungan SSKAD tersebut dilanjutkan oleh Lemhanas, dalam pemikiran Lemhanas telah ada kemajuan konseptual berupa ditemukanya unsur-unsur dari tata kehidupan nasional berupa panca gatra yakni ideologi, politik, ekonomi, sosial, dan militer (IPOLESKOM). Selanjutnya pada tahun 1969 lahirlah istilah Ketahanan Nasional yang menjadi pertanda dari ditinggalkanya konsep kekuatan, meskipun dalam ketahanan nasional sendiri terdapat konsep kekuatan. Ketahanan Nasional pada tahun 1969 didefinisikan sebagai "Keuletan dan daya tahan suatu bangsa yang mengandung kemampuan mengembangkan kekuatan nasional yang ditujukan untuk menghadapi segala ancaman yang membahayakan kelangsungan hidup negara dan bangsa Indonesia".

Konsepsi ketahanan nasional semakin berkembang, pada tahun 1972 konsepsi ketahanan nasional diperluas menjadi hakekat ancaman, tantangan, hambatan dan gangguan (ATHG). Selanjutnya konsepsi Ketahanan Nasional diperbaharui dan diartikan sebagai : "Kondisi dinamis suatu bangsa yang berisi keuletan dan ketangguhan yang mengandung kemampuan untuk mengembangkan kekuatan nasional, didalam menghadapi dan mengatasi segala tantangan, ancaman, hambatan dan gangguan baik yang datang luar maupun dari dalam, yang langsung maupun tidak langsung yang membahayakan identitas, integritas, kelangsungan hidup bangsa dan negara, serta perjuangan mengejar tujuan perjuangan nasional". Dari sini kita mengenal tiga konsepsi Ketahanan Nasional Indonesia. yakni konsepsi tahun 1968, tahun 1969 dan tahun 1972. Menurut konsepsi tahun 1968 dan 1969 ketahanan nasional adalah keuletan dan 
daya tahan, sedang pada konsepsi 1972 ketahanan nasional merupakan suatu kondisi dinamik yang berisi keuletan dan ketangguhan. Jika pada dua konsepsi sebelumnya yakni tahun 1968 dan 1969 konsepsi ketahanan nasional dikenal istilah IPOLEKSOM (Panca Gatra) dalam konsepsi tahun 1972 diperluas dan disempurnakan berdasar asas Asta Gatra. Asta gatra sendiri terdiri dari panca gatra (konsepsi ketahanan nasional tahun 1968 dan 1969) dan tri gatra yang meliputi penduduk, wilayah dan sumber daya alam (Haryomataraman dalam Panitia Lemhanas, 1980: 95-96).

Pada tahun-tahun selanjutnya konsepsi ketahanan nasional dimasukkan ke dalam Garis Besar Haluan Negara (GBHN), yakni mulai GBHN 1973 sampai dengan GBHN 1998. Adapun rumusan konsep ketahanan nasional dalam GBHN tahun 1998 adalah sebagai berikut:

1. Untuk tetap memungkinkan berjalannya pembangunan nasional yang selalu harus menuju ke tujuan yang ingin dicapai dan agar dapat secara efektif dielakkan dari hambatan, tantangan, ancaman dan gangguan yang timbul baik dari luar maupun dari dalam, maka pembangunan nasional diselenggarakan melalui pendekatan Ketahanan Nasional yang mencerminkan keterpaduan antara segala aspek kehidupan nasional bangsa secara utuh dan menyeluruh.

2. Ketahanan Nasional adalah kondisi dinamis yang merupakan integrasi dari kondisi tiap aspek kehidupan bangsa dan negara. Pada hakekatnya Ketahanan Nasional adalah kemampuan dan ketangguhan suatu bangsa untuk dapat menjamin kelangsungan hidup menuju kejayaan bangsa dan negara. Berhasilnya pembangunan nasional akan meningkatkan Ketahanan Nasional. Selanjutnya Ketahanan Nasional yang tangguh akan mendorong pembangunan nasional.

3. Ketahanan Nasional meliputi ketahanan ideologi, ketahanan politik, ketahanan ekonomi, ketahanan sosial budaya dan ketahanan pertahanan keamanan. 
4. Ketahanan ideologi adalah kondisi mental bangsa Indonesia yang berlandaskan keyakinan akan kebenaran ideologi Pancasila yang mengandung kemampuan untuk menggalang dan memelihara persatuan dan kesatuan nasional dan kemampuan menangkal penetrasi ideologi asing serta nilai-nilai yang tidak sesuai dengan kepribadian bangsa

5. Ketahanan politik adalah kondisi kehidupan politik bangsa Indonesia yang berlandaskan demokrasi politik berdasarkan Pancasila dan Undang Undang Dasar 1945 yang mengandung kemampuan memelihara sistem politik yang sehat dan dinamis serta kemampuan menerapkan politik luar negeri yang bebas dan aktif

6. Ketahanan ekonomi adalah kondisi kehidupan perekonomian bangsa yang berlandaskan demokrasi ekonomi yang berdasarkan Pancasila yang mengandung kemampuan memelihara stabilitas ekonomi yang sehat dan dinamis serta kemampuan menciptakan kemandirian ekonomi nasional dengan daya saing yang tinggi dan mewujudkan kemakmuran rakyat yang adil dan merata

7. Ketahanan sosial budaya adalah kondisi kehidupan sosial budaya bangsa yang dijiwai kepribadian nasional berdasarkan Pancasila yang mengandung kemampuan membentuk dan mengembangkan kehidupan sosial budaya manusia dan masyarakat Indonesia yang beriman dan bertakwa terhadap Tuhan Yang Maha Esa, rukun, bersatu, cinta tanah air, berkualitas, maju dan sejahtera dalam kehidupan yang serba selaras, serasi seimbang serta kemampuan menangkal penetrasi budaya asing yang tidak sesuai dengan kebudayaan nasional

8. Ketahanan pertahanan keamanan adalah kondisi daya tangkal bangsa yang dilandasi kesadaran bela negara seluruh rakyat yang mengandung kemampuan memelihara stabilitas pertahanan keamanan negara yang dinamis, mengamankan pembangunan dan hasil-hasilnya serta 
kemampuan mempertahankan kedaulatan negara dan menangkal segala bentuk ancaman

9. Sampai saat ini LEMHANNAS telah menghasilkan tiga konsep Ketahanan Nasional; yaitu konsepsi tahun 1968; 1969 dan 1972. Konsepsi terakhir merupakan penyempurnaan dari konsepsi sebelumnya. Menurut konsepsi 1968 dan 1969 Ketahanan nasional adalah keuletan dan ketangguhan.

\section{B. Falsafah Ketahanan Nasional}

Pengertian falsafah dalam KBBI adalah anggapan, gagasan, dan sikap batin yang paling dasar yang dimiliki oleh orang atau masyarakat, falsafah juga diartikan sebagai pandangan hidup. Falsafah ketahanan nasional berarti gagasan yang mendasari lahirnya ketahanan nasional, berbicara mengenai lahirnya ketahanan nasional di Indonesia maka hal ini sangat erat kaitannya dengan sejarah ketahanan nasional, di mana telah dijelaskan bada sub bab sejarah ketahanan nasional. Berawal dari kemerdekaan Indonesia, maka falsafah ketahanan nasional mulai terbentuk. Sejak proklamasi 17 Agustus 1945, kehidupan bangsa Indonesia tidak luput dari gejolak dan ancaman baik dari dalam maupun dari luar negeri yang dapat membahayakan eksistensi Negara Kesatuan Republik Indonesia (NKRI), seperti:

1. Agresi Militer Belanda.

2. Gerakan Separatis : PKI, DI/TII dan lain-lain.

3. Ditinjau dari geopolitik dan geostrategis dengan posisi geografis, potensi Sumber Daya Alam serta jumlah dan kemampuan penduduk, telah menempatkan bangsa Indonesia menjadi ajang persaingan dan perebutan negaranegara besar, sehingga menimbulkan dampak negatif yang dapat membahayakan kelangsungan dan eksistensi negara Indonesia.

Meskipun dihadapkan terhadap tantangan tersebut, NKRI tetap tegak berdiri sebagai suatu bangsa yang merdeka, bersatu dan berdaulat, hal itu menunjukan bangsa Indonesia 
mempunyai keuletan dan kemampuan yang mengandung kemampuan mengembangkan kekuatan nasional, sehingga dapat menghadapi Ancaman, Gangguan, Hambatan dan Tantangan (AGHT). Negara Indonesia adalah negara hukum bukan berdasarkan kekuasaan belaka, dan kesemuannya ditunjukan untuk menjaga ketertiban seluruh masyarakat Indonesia.Negara Indonesia adalah negara yang mempunyai UUD 1945 sebagai konsutitusinya, di mana sistem pemerintahan negara tertuang di dalamnya, sehingga kondisi kehidupan nasional merupakan pencerminan ketahanan Nasional yang didasari oleh:

1. Pancasila sebagai landasan idiil.

2. UUD 1945 sebagai landasan konstitusionil.

3. Wawasan Nusantara sebagai landasan visional.

Untuk itu bangsa Indonesia harus memiliki keuletan dan ketangguhan yang mengandung kemampuan mengembangkan kekuatan nasional sehingga berhasil mengatasi setiap bentuk tantangan ancaman hambatan dan gangguan dari manapun datangnya. Falsafah dan ideologi juga menjadi pokok pikiran. Hal ini tampak dari makna falsafah dalam Pembukaan UUD 1945 yang berbunyi sebagai berikut:

1. Alinea pertama menyebutkan:

"Bahwa sesungguhnya kemerdekaan itu hak segala bangsa dan oleh sebab itu maka penjajahan di atas dunia harus dihapuskan, karena tidak sesuai dengan perikemanusiaan dan perikeadilan."

Maknanya: Kemerdekaan adalah hak asasi manusia.

2. Alinea kedua menyebutkan:

"dan perjuangan kemerdekaan Indonesia telah sampailah kepada saat yang berbahagia dengan selamat sentosa mengantarkan rakyat Indonesia ke depan pintu gerbang kemerdekaan Negara Indonesia yang merdeka, berdaulat, adil dan makmur."

Maknanya: adanya masa depan yang harus diraih (cita-cita). 
3. Alinea ketiga menyebutkan:

"Atas berkat rahmat Allah Yang Maha Kuasa dan dengan didorong oleh keinginan luhur supaya berkehidupan kebangsaan yang bebas maka rakyat Indonesia menyatakan dengan ini Kemerdekaannya."

Maknanya: bila Negara ingin mencapai cita-cita maka kehidupan berbangsa dan bernegara harus mendapat ridlo Allah yang merupakan dorongan spiritual.

4. Alinea keempat menyebutkan:

"Kemerdekaan dari pada itu untuk membentuk suatu pemerintahan Negara Indonesia yang melindungi segenap bangsa Indonesia dan seluruh tumpah darah Indonesia dan untuk memajukan kesejahteraan umum, mencerdaskan kehidupan bangsa dan ikut melaksanakan ketertiban dunia yang berdasarkan kemerdekaan,perdamaian abadi dan keadilan social, maka disusunlah kemerdekaan kebangsaan Indonesia itu dalam susunan Negara Republik Indonesia yang berkedaulatan rakyat dan berdasarkan:"

a. Ketuhanan Yang Maha Esa

b. Kemanusiaan yang adil dan beradab

c. Persatuan Indonesia

d. Kerakyatan yang dipimpin oleh hikmat kebijaksanaan dalam permusyawaratan/perwakilan serta dengan mewujudkan keadilan sosial bagi seluruh bagi seluruh rakyat Indonesia.

Asas Ketahanan Nasional Indonesia adalah tata laku berdasarkan nilai-nilai Pancasila, UUD1945 dan Wawasan Nusantara, yang terdiri dari :

1. Asas Kesejahteraan dan Keamanan.

Kesejahteraan dan keamanan dapat dibedakan tetapi tidak dapat dipisahkan dan merupaka kebutuhan manusia yang mendasar dan esensial. Dengan demikian, kesejahteraan dan keamanan merupakan asas dalam sistem kehidupan nasional. Tanpa Kesejahteraan dan keamanan, sistem kehidupan nasional tidak akan dapat berlangsung. Kesistem kehidupan nasional itu sendiri. Kesejahteraan 
maupun keamanan harus selalu ada, berdampingan pada kondisi apapun. Dalam kehidupan nasional, tingkat kesejahteraan dan keamanan nasional yang dicapai merupakan tolak ukur Ketahanan Nasional.

2. Asas Komprehensif Integral atau Menyeluruh Terpadu

Sistem kehidupan nasional mencakup segenap aspek kehidupan bangsa dalam bentuk perwujudan persatuan dan perpaduan yang seimbang, serasi, dan bernegara. Ketahanan Nasional mencakup ketahanan segenap aspek kehidupan bangsa secara utuh, menyeluruh, dan terpadu( komprehensif integral).

3. Asas Mawas ke Dalam dan Mawas Keluar

Sistem kehidupan nasional merupakan perpaduan segenap aspek kehidupan bangsa yang saling berinteraksi dengan lingkungan sekelilingnya. Dalam proses interaksi tersebut dapat timbul berbagai dampak, baik yang bersifat positif maupun negatif. Untuk itu diperlukan sikap mawas kedalam dan keluar.

a. Mawas ke dalam

Mawas kedalam bertujuan menumbuhkan hakikat, sifat dan kondisi kehidupan nasional itu sendiri berdasarkan nilai-nilai kemandirian yang proposrional untuk meningkatkan kualitas derajat kemandirian bangsa yangulet dan tangguh. Hal ini tidak berarti bahwa Ketahanan Nasional mengandung sikap isolasi atau nasionalisme sempit.

b. Mawas ke luar

Mawas keluar bertujuan untuk dapat mengantisipasi dan berperan serta mengatasi dampak lingkungan strategis luar negeri dan menerima kenyataan adanaya interaksi dan ketergantungan dengan dunia internasional. Kehidupan nasional harus mampu mengembangkan kekuatan nasional untuk memberikan dampak keluar dalam bentuk daya tangkal dan daya tawar. Interaksi dengan pihak lain diutamakan dalam bentuk kerjasama yang saling menguntungkan. 
4. Asas Kekeluargaan

Asas kekeluargaan mengandung keadilan, kearifan, kebersamaan, kesamaan, gotong royong, tenggang rasa, dan tanggung jawab dalam kehidupan bermasyarakat, berbangsa, dan bernegara. Asas ini mengakui adanya perbedaan. Perbedaan tersebut harus dikembangkan secara serasi dalam hubungan kemitraan agar tidak berkembang menjadi konflik yang bersifat saling menghancurkan.

Tujuan ketahanan nasional pada dasarnya untuk menghadapi ancaman, tantangan, hambatan, dan gangguan (ATHG). Jadi semakin kuat ketahanan nasional suatu bangsa semakin dapat menjamin kelangsungan hidup atau survival hidup suatu bangsa dan Negara. Oleh karena itu, sekarang yang dibutuhkan adalah bagaimana membangun ketahanan nasional nasional secara intens melalui pembinaan tingkat ketahanan dari mulai ketahanan nasional, ketahanan daerah, ketahanan lingkungan, ketahanan keluarga dan ketahanan pribadi. Melalui pembangunan ketahanan nasional dengan pendekatan dari bawah maka diharapkan dapat tercapai kondisi keamanan nasional yang menjamin kelangsungan hidup bangsa dan Negara dan sekaligus pelaksanaan pembangunan di berbagai daerah.

\section{Konsep Ketahanan Nasional}

Konsepsi pengembangan kekuatan nasional melalui pengaturan dan penyelenggaraan kesejahteraan dan keamanan yang seimbang, serasi dan selaras dalam seluruh aspek kehidupan secara utuh dan terpadu berlandaskan Pancasila dan UUD 1945 dan wawasan nusantara dengan kata lain konsepsi ketahanan nasional merupakan pedoman untuk meningkatkan keuletan dan ketangguhan bangsa yang mengandung kemampuan mengembangkan kekuatan nasional dengan pendekatan kesejahteraan dan keamanan. Kesejahteraan dapat digambarkan sebagai kemampuan bangsa dalam menumbuhkan dan mengembangkan nilai-nilai 
nasionalnya demi sebesar-besarnya kemakmuran yang adil dan merata, rohaniah dan jasmaniah. Sedangkan keamanan adalah kemampuan bangsa melindungi nilai-nilai nasional terhadap ancaman dari luar maupun dari dalam.

Konsepsi ketahanan nasional juga diartikan sebagai konsepsi nasional dalam pencapaian tujuan nasional yang pada intinya tercapainya keamanan dan kesejahteraan bagi seluruh rakyat Indonesia, yang menjadi tugas dan tanggung jawab pemerintahan negara. Adapun rumusan tujuan nasional sebagaimana yang diamatkan dalam pembukaan UUD RI 1945 ialah membentuk suatu pemerintahan negara yang melindungi segenap bangsa Indonesia dan seluruh tumpah darah Indonseia dan memajukan kesejahteraan umum, mencerdaskan kehidupan bangsa dan ikut melaksanakan ketertiban dunia yang berdasarkan kemerdekaan, perdamaian abadi dan keadilan sosial. Untuk mencapai tujuan nasional tersebut, diperlukan ketahanan nasional yakni kondisi yang mampu menghadapi dan mengatasi segala tantangan, ancaman, hambatan dan gangguan. Kemudian untuk mewujudkan ketahanan nasional diperlukan konsepsi ketahanan nasional yakni konsepsi pengaturan dan penyelenggaraan keamanan dan kesejahteraan secara seimbang, serasi dan selaras yang dilaksanakan melalui pembangunan nasional dan pembangunan daerah sebagai bagian integral dari pembangunan nasional. Hal ini berarti, pada saat kita menyelesaikan masalah keamanan harus ikut dipikirkan kesejahteraan, demikian pula sebaliknya. Untuk menjamin identitas, integrasi dan kelangsungan hidup bangsa dan negara serta perjuangan mencapai tujuan nasional dapat dijelaskan seperti dibawah ini:

1. Ketangguhan

Ketangguhan adalah kekuatan yang menyebabkan seseorang atau sesuatu dapat bertahan, kuat menderita atau dapat menanggulangi beban yang dipikulnya. 